\title{
Niche enlargement as a consequence of co-existence: a case study
}

\author{
Mazzoni, R. ${ }^{a *}$, Marques, PS. ${ }^{a}$, Rezende, $C F^{a, c}$ and Iglesias-Rios, $R .^{b}$ \\ aDepartamento de Ecologia, Instituto de Biologia Roberto Alcantara Gomes, \\ Universidade do Estado do Rio de Janeiro - UERJ, Rua São Francisco Xavier, 524, \\ CEP 20550-013, Rio de Janeiro, RJ, Brazil \\ 'Departamento de Ecologia, Instituto de Biologia, Universidade Federal do Rio de Janeiro - UFRJ, \\ CP 68020, Rio de Janeiro, RJ, Brazil \\ 'Departamento de Biologia, Universidade Federal do Ceará - UFC, CEP 60455-970, Fortaleza, CE, Brazil \\ *e-mail: mazzoni@uerj.br \\ Received March 22, 2011 - Accepted July 04, 2011 - Distributed May 31, 2012 \\ (With 4 figures)
}

\begin{abstract}
Spatio-temporal changes in the diet, niche breadth and niche overlap of two species of Characidium from three different sites along a Neotropical coastal stream were studied during a dry and rainy season. Seasonal changes were restricted to the occurrence of plant items in the stomach contents. The relative importance of food items in the diet of both species varied across sites, but Diptera, Ephemeroptera, Simuliidae, Trichoptera and Coleoptera larvae were always the main prey items. Contrary to the expected pattern, values of the niche breadth were higher at the site where Characidium species co-existed and niche overlapped at this site indicated 52\% ( $\mathrm{p}=0.52)$ of feeding overlap.
\end{abstract}

Keywords: neotropical characidae, coastal stream, close related species.

\section{Ampliação do nicho como consequência da co-existência: um estudo de caso}

\begin{abstract}
Resumo
Variações espaço-temporal na dieta, na amplitude e na sobreposição de nicho foram estudadas para duas espécies de Characidium de três localidades distintas de um riacho costeiro da região Neotropical, considerando-se as estações seca e chuvosa. As alterações sazonais na dieta foram restritas à presença/ausência de itens vegetais nos conteúdos estomacais. A importância relativa dos itens alimentares, de ambas as espécies, variou entre as localidades de estudo; porém, as larvas de Diptera, Ephemeroptera, Simuliidae, Trichoptera e Coleoptera foram sempre as presas mais consumidas. Em oposição ao padrão esperado, os valores de amplitude de nicho foram maiores na localidade em que as duas espécies de Characidium ocorreram em sintopia e a sobreposição de nicho, nessa localidade, indicou 52\% $(\mathrm{p}=0,52)$ de sobreposição alimentar.
\end{abstract}

Palavras-chave: characidae neotropical, riachos costeiros, espécies relacionadas.

\section{Introduction}

The idea that competition is an important mechanism in the organization of populations and communities has been considered the cornerstone of ecological and evolutionary theory. Since Hutchinson (1957) questioned the mechanisms that allow sympatric species to partition resources and co-exist, it has been noted that in highly diverse communities, realized niches and niche breadth are reduced as a consequence of competition (Mac-Arthur, 1972). As a result of these findings, it is thought that natural selection favours specialization through competition, thereby linking competition to specialization and a reduction of niche breadth among coexisting correlated species.

Across many animal groups, tropical communities support higher diversity than temperate ones, and according to the resource partitioning theory one would therefore

expect a more specialist species. Many years of study have not resolved whether this is the case or not as various studies have shown that both trophic specialists (Vojtech et al., 2002) and trophic generalists (Dyer et al., 2007) predominate in the tropics.

The intensity of competition is traditionally estimated using some measure of similarity or overlap in the resources used by co-occurring species (Pusey and Bradshaw, 1996), but the observed patterns vary among environments and/or climatic regions (Zaret and Rand, 1971). The absence of competition in tropical regions has often been attributed to resource partitioning (e.g. Uieda et al., 1997; Esteves and Lobón-Cerviá, 2001; Deus and Petrere-Junior, 2003; Fogaça et al., 2003; Barreto and Aranha, 2006) because of the high feeding plasticity (Gerking, 1994; Araújo-Lima et al., 
1995; Kido, 2001) associated with the high diversity of food resources in these areas (Lowe-McConnell, 1979; Winemiller, 1989; Jepsen et al., 1997; Winemiller and Jepsen, 1998).

In the present work, we studied the spatio-temporal variation in the feeding habits of two close-related characins: Characidium interruptum (Pellegrin, 1909) and Characidium cf. vidali (Travassos, 1967) from a Neotropical stream. Following Mac-Arthur (1972), we hypothesized that for both Characidium species realized niche vary among sites and niche breadth is reduced in sites were the species co-exist. Thus, we focused on the potential differences in the feeding patterns, considering sites where species co-occurred and sites where they did not.

\section{Methods}

Mato Grosso is a $3^{\text {rd }}$ order stream $\left(22^{\circ} 55^{\prime} \mathrm{S}\right.$ and $42^{\circ} 35^{\prime} \mathrm{W}$ ) draining the east-facing watershed of the Serra do Mar mountains in Rio de Janeiro State, Brazil (Figure 1). Deforested areas predominate in the lowlands but there are still some areas where the secondary Atlantic rain forest dominates in the headwaters. Water level is solely regulated by rainfall and run-off, with abundant summer (December to March) rain. We took samples from three sites along the Mato Grosso stream-bed: Site 1 (headwater, only Characidium cf. vidali occurs), Site 2 (midstream, both Characidium occur) and Site 3 (downstream, only C. interruptum occurs). For the purpose of the present study, environmental parameters, of each sampling site, were quantified according to bathymetric maps based on transversal transects registered within an interval of $5 \mathrm{~m}$ long, from the lower to the upper section of the sampling site (Table 1).

Food availability was estimated for the three study sites using a Surber $\left(0.09 \mathrm{~m}^{2}\right.$ sampling area, $180 \mu \mathrm{m}$ mesh net). We collected three samples of each substratum type (rock, sand and leaf litter) at each study site. Each sample was wrapped in a plastic bag and fixed in $80 \%$ ethanol. In the laboratory, samples were sieved (mesh $180 \mu \mathrm{m})$ and washed under running water and then screened. Then, macroinvertebrates and plant parts were separated from the substrate and counted. The macroinvertebrates were identified according to Mugnai et al. (2010). Densities of macroinvertebrates and plant parts were recorded as the number of individuals per $\mathrm{m}^{-2}$ (area of the Surber frame) (Table 2).

Fish were sampled by electrofishing (900 W, 2-3 A) during the rainy (January and March) and dry seasons (June and July) of 2007. Voucher specimens of

Table 1. Altitude (in meters); percentage of occurrence of the environmental descriptors splitted in three categories: i) water dynamics-pools, riffles and runs; ii) kind of substrata-mud, sand, gravel, rock and iii) riparian vegetationcanopy and marginal vegetation obtained from transects of $5 \mathrm{~m}$ apart during the four sampling periods (January, March, June and July of 2007) in the three sampling sites (S1-site 1, S2-site 2 and S3-site 3) of the Mato Grosso system. Distance $=$ distance from the river mouth

\begin{tabular}{lccc}
\hline \multicolumn{1}{c}{$\begin{array}{c}\text { Environmental } \\
\text { descriptors }\end{array}$} & S1 & S2 & S3 \\
\hline Altitude $(\mathrm{m})$ & 150 & 90 & 40 \\
Pools & 19.3 & 22 & 0 \\
Rifles & 70.7 & 50.7 & 98.5 \\
Runs & 10 & 27.3 & 1.5 \\
Mud & 11 & 21.1 & 6.3 \\
Sand & 31.7 & 26.3 & 23.2 \\
Gravel & 52.3 & 51.4 & 59.2 \\
Rock & 5 & 1.2 & 11.3 \\
Canopy & 95 & 90 & 90 \\
Marginal vegetation & 5 & 10 & 10 \\
Distance $(m)$ & 15 & 13.5 & 3 \\
Conductivity $\left(\mu \mathrm{S} . c m^{-1}\right)$ & 83 & 105 & 100 \\
\hline
\end{tabular}

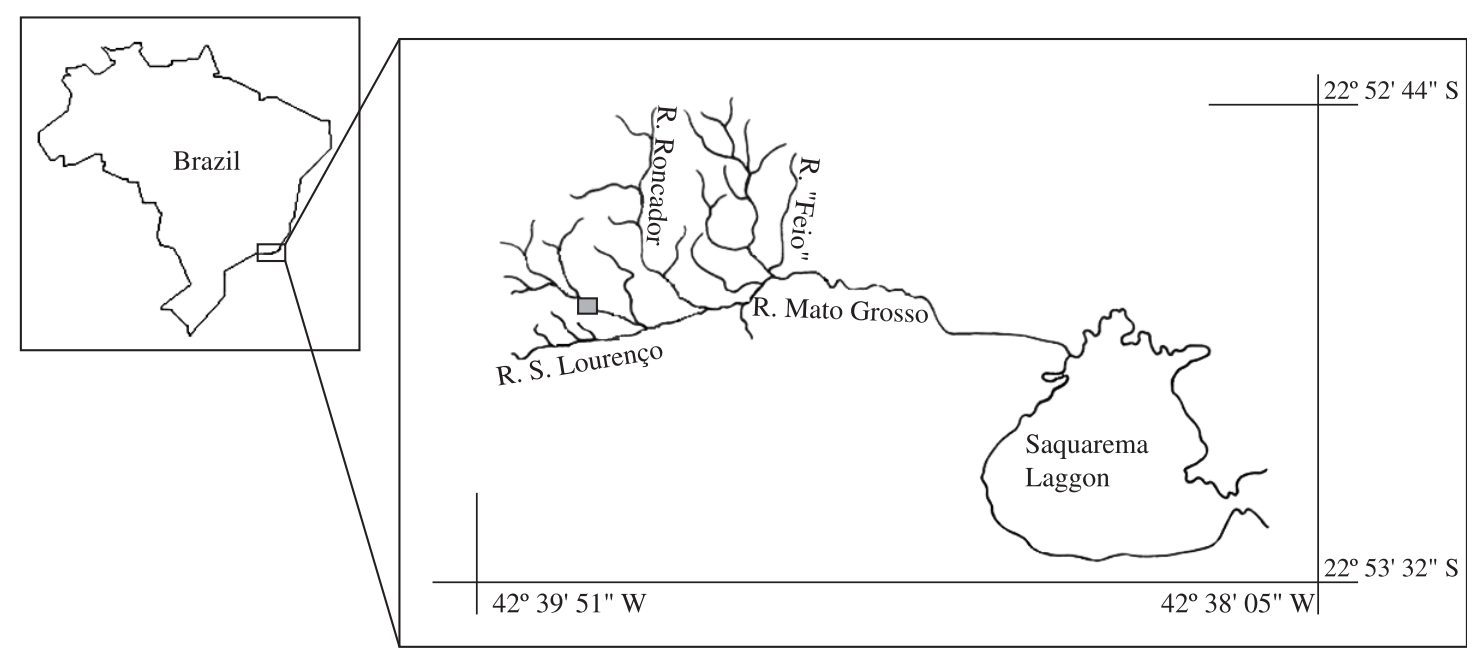

Figure 1. Mato Grosso fluvial system showing the sample site (grey square). 
Table 2. Food items available (ind $\times \mathrm{m}^{-2}$ ) and consumed (IAi) by Characidium species at the three study sites, of the Mato Grosso stream, Rio de Janeiro, Brazil. Arachnida = Acarina and Araneae; Ephemeroptera nymph = Baetidae and Ephemeroptera; Coleoptera larvae $=$ Curculionidae; Trichoptera larvae $=$ Hydrobiosidae and Hydropsychidae; other Diptera larvae $=$ Ceratopogonidae, Chironomidae, Culicidae, Diptera, Dixidae, Dolichopodidae e Empididae.

\begin{tabular}{|c|c|c|c|c|c|c|c|c|c|c|c|}
\hline \multirow{3}{*}{ Items } & \multicolumn{3}{|c|}{$\begin{array}{c}\text { Environmental } \\
\text { availability }\end{array}$} & \multicolumn{4}{|c|}{ Characidium cf. vidali } & \multicolumn{4}{|c|}{ Characidium interruptum } \\
\hline & \multirow{2}{*}{ Site 1} & \multirow{2}{*}{ Site 2} & \multirow{2}{*}{ Site 3} & \multicolumn{2}{|c|}{ Site 1} & \multicolumn{2}{|c|}{ Site 2} & \multicolumn{2}{|c|}{ Site 2} & \multicolumn{2}{|c|}{ Site 3} \\
\hline & & & & Rainy & Dry & Rainy & Dry & Rainy & Dry & Rainy & Dry \\
\hline Bivalve* & 10 & 7 & 9 & 0.01 & 0.01 & & & & 0.16 & & \\
\hline Arachnida* & 6 & 11 & 7 & & 0.02 & & & & 0.93 & & \\
\hline Ephemeroptera nymph* & 143 & 49 & 184 & 2.98 & 3.00 & 15.69 & 12.55 & 37.88 & 20.4 & 93.5 & 78.31 \\
\hline Odonata nymph* & 14 & 2 & 4 & 0.03 & 1.16 & & & 8.14 & 6.81 & 0.02 & 0.1 \\
\hline Coleoptera larvae* & 49 & 13 & 23 & 0.18 & & & & & 0.31 & 1.55 & 1.97 \\
\hline Hymenoptera** & 22 & 1 & 4 & & & & & & & 0.12 & \\
\hline Trichoptera larvae* & 26 & 5 & 27 & 36.93 & 13.23 & 30.92 & 33.77 & 3.75 & 3.73 & 1.39 & 5.8 \\
\hline Lepidoptera larvae $* *$ & 6 & 1 & & 0.08 & & & & & & & \\
\hline Other Diptera larvae * & 514 & 171 & 363 & 0.93 & 8.71 & 11.62 & 11.73 & 33.71 & 45.37 & 0.75 & 2.96 \\
\hline Simuliidae larvae* & 71 & 32 & 31 & 58.86 & 68.43 & 41.81 & 31.78 & 16.52 & 21.82 & 2.69 & 1.32 \\
\hline Plant Matter $* *+$ Algae* & 300 & 297 & 323 & & 5.43 & & 10.17 & & 0.47 & & 9.62 \\
\hline
\end{tabular}

*Autochthonous; **allochthonous.

Characidium cf. vidali and Characidium interruptum were deposited in the Museu Nacional do Rio de Janeiro (MNRJ 29958, 29980 and MNRJ 29969, 29970, 29971, respectively). In order to access feeding habits, at each sampling occasion and study site, we randomly selected approximately 20 specimens of each species. Feeding habits were assessed using a sample of 295 specimens: $93 C V$ from Site 1; $51 C V$ and 63 CI from Site 2; and $88 C I$ from Site 3. Sampled fish were euthanized by a blow to the cranium, stomachs were removed and their contents preserved in $5 \%$ formalin.

Gut content analyses were performed under a stereoscopic microscope using the Volumetric (V) and Frequency of Occurrence $\left(\mathrm{F}_{\mathrm{O}}\right)$ methods (Hynes, 1950; Hyslop, 1980). For each species, the relative importance of each consumed item was assessed by the Alimentary Index (IA I $_{\mathrm{i}}$ proposed by Kawakami and Vazzoler (1980) and adapted by Hahn et al. (1997) (Equation 1):

$\mathrm{IA}_{\mathrm{i}}=\left(\mathrm{F}_{\mathrm{i}} \times \mathrm{V}_{\mathrm{i}}\right) / \Sigma\left(\mathrm{F}_{\mathrm{i}} \times \mathrm{V}_{\mathrm{i}}\right) \times 100$

where $\mathrm{F}_{\mathrm{i}}$ and $\mathrm{V}_{\mathrm{i}}$ are the Frequency of Occurrence and Volume of each food item, respectively. Patterns in diet similarities among sites and seasons, as well as patterns in food availability were analyzed based on the food availability and $\mathrm{IA}_{\mathrm{i}}$ values (Table 2) using a cluster analysis based on the UPGMA method with Bray Curtis distances (McCune and Mefford, 1997).

The amplitude of trophic niche (diet amplitude) of each species was estimated for each species and study site using the Shannon's Index of niche breadth (S). This index varies from 0 (the species eat only one kind of food) to 1 (the species use many kinds of food and each kind is equally consumed). Trophic niche overlap was estimated at site 2 according to Pianka's Index of niche overlap (P) (Krebs, 1999). This index varies from 0 (no feeding overlap) to 1 (complete feeding overlap). Following Grossman (1986), the values of feeding overlap were considered: high $(>0.60)$, medium $(0.4-0.6)$ and low $<0.4)$. Temporal and spatial differences in mean values of $S$ were tested with a t-test (Zar, 1999). Spatio-temporal differences in food availability were also tested with a Kruskal-Wallis test (Zar, 1999).

\section{Results}

Environmental parameters were very similar for each sampling site (Table 1) and no significant differences $(\mathrm{H}=1.91 ; \mathrm{p}=0.39)$ in prey availability were found between them (Table 2). Seasonal differences in feeding habits were only related to the relative consumption of plant and animal matter; both species consumed plant matter only during the dry season (Table 2). The cluster analysis (Figure 2) based on food consumption by both $C$. vidali and $C$. interruptum indicated a high similarity between the rainy and dry seasons for all study sites.

The diet of both species was based mainly on autochthonous insects, although some allochthonous items were also observed (Table 2). C. vidali consumed ten food items at Site 1 and five food items at Site 2. C. interruptum consumed nine food items at Site 2 and eight food items at Site 3 . Niche breadth differed between sites and was larger at Site 2 but, with no significant interspecific differences ( $t$-test; $1 \mathrm{df} ; \mathrm{p}=0.18$ ) (Figure 3).

The relative importance $\left(\mathrm{IA}_{\mathrm{i}}\right.$ ) of each food item varied across sites for both species despite the fact that the availability of food items did not vary (Table 2; Figure 4). At Site 1 , food items consumed by $C$. vidali were mainly Trichoptera and Simuliidae. At Site 2, where C. vidali and C. interruptum co-existed, food items were more diverse; both $C$. vidali and $C$. interruptum fed on the same items, 
Bray - curtis distance

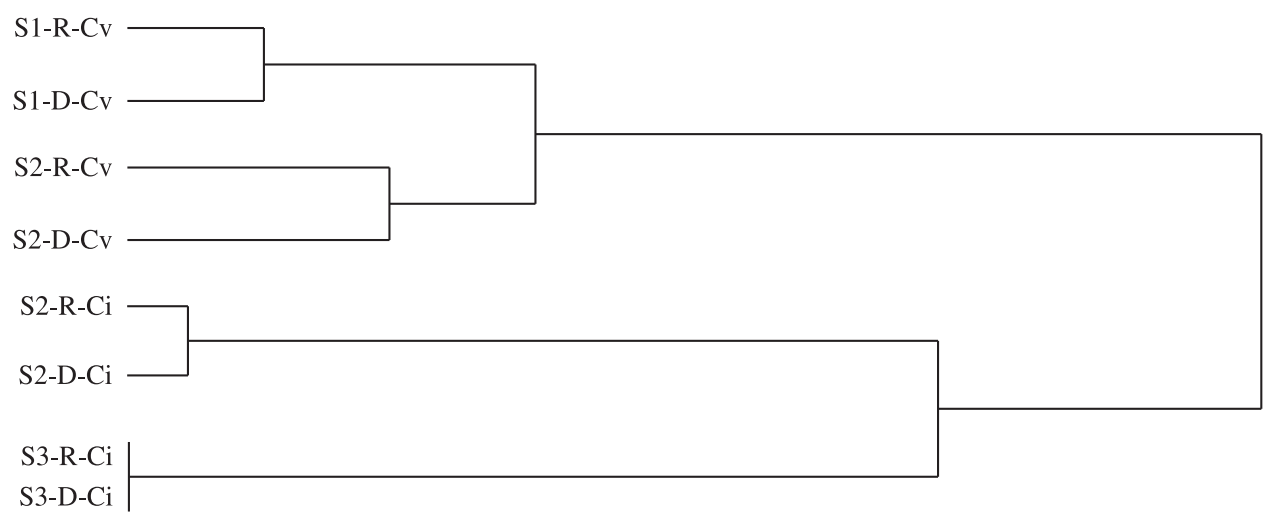

Figure 2. Dendrogram of similarity between site and seasons (Bray Curtis distance) based on an Alimentary Index (IAi) matrix for sites 1 (S1), 2 (S2) and 3 (S3) during the rainy (R) and dry (D) seasons for Characidium cf. vidali (CV) and Characidium interruptum (CI) from Mato Grosso stream, Rio de Janeiro, Brazil.

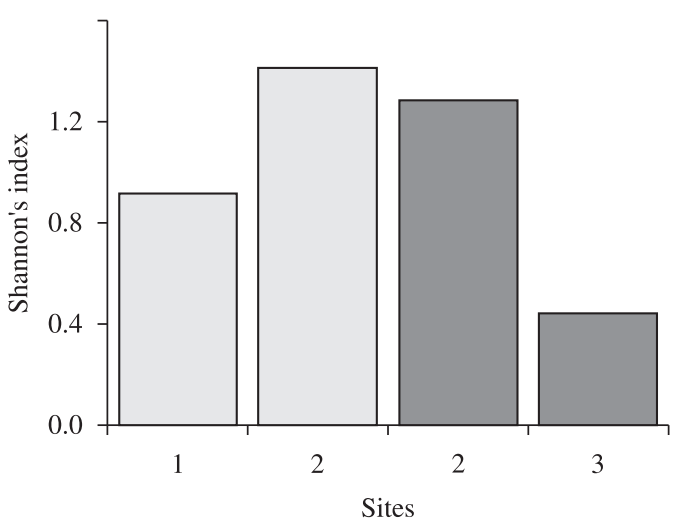

Figure 3. Spatial variation of Shannon's Index of niche breadth values of Characidium cf. vidali (light grey) and Characidium interruptum (dark grey) inhabiting sites 1, 2 and 3 from Mato Grosso stream, Rio de Janeiro, Brazil.

mainly Ephemeroptera, Trichoptera, Diptera and Simuliidae, but interspecific differences in the relative consumption of each food item were noted; $C$. vidali fed mainly upon Simuliidae and Trichoptera $\left(\mathrm{IA}_{\mathrm{i}}=72.7\right.$ and 65.6, rainy and dry seasons, respectively) whereas $C$. interruptum fed mainly on Diptera and Ephemeroptera $\left(\mathrm{IA}_{\mathrm{i}}=71.59\right.$ and 65.77 , rainy and dry seasons, respectively). At Site 3 C. interruptum fed on Ephemeroptera with a low incidence of Simuliidae and Trichoptera. Pianka's niche overlap index $(\mathrm{P})$ indicated $52 \%$ of feeding overlap $(\mathrm{P}=0.52)$ at Site 2, where the species coexisted.

\section{Discussion}

According to Ibañez et al. (2009) omnivorous are a species which consistently feed on substantial proportions of both plant and animal material and carnivorous/invertivorous are the species which feed on crustaceans, oligochaetes, mollusks and/or insects. Although the studied Characidium species presented both animal and vegetal items in their diet, the amount of consumed plant items were very low and rarely registered in stomachs (never exceeding $10 \%$ of IAi) while larvae and nymphs of insects were the most important items. These results support the recurrent invertivorous classification used for many different Characidium species (e.g. Godoy, 1975; Costa, 1987; Sabino and Castro, 1990; Castro and Casatti, 1997; Uieda et al., 1997; Aranha et al., 2000; Aranha et al., 2000; Araújo et al., 2005; Barreto and Aranha, 2006; Ferreira, 2007; Gomiero and Braga, 2008) but raises the question about changes in the consumption of food items and feeding plasticity of fish species.

In the study area, apart from the seasonal changes in water temperature and photoperiod, the occurrence of summer spates are probably the most typical environmental factor affecting resources as food availability (Súarez, 2008; Mazzoni and Rezende, 2009; Mazzoni et al., 2010a; Mazzoni et al., 2010b). The presence of plant matter was the only seasonal difference in the diet of both Characidium species and probably resulted from changes in plant availability owing to environmental changes associated with seasonality. Plant matter was a food item during the dry season when stream volume and water velocity were at their minimum (Mazzoni and Lobón-Cerviá, 2000), reducing the availability of aquatic insect fauna (Pinto and Uieda, 2007) and giving rise to conditions conducive to the proliferation of in-stream marginal vegetation and peryphiton, making it more available as a food resource for fish fauna (Carvalho and Uieda, 2010).

During the dry season (= lower temperature in southeast Brazil), insect densities decline in streams (i.e. Prejs and 
Bray - curtis distance

\begin{tabular}{lccc}
$2.2 \mathrm{E}-03$ & $1.2 \mathrm{E}-01$ & $2.5 \mathrm{E}-01$ & $3.7 \mathrm{E}-01$ \\
\hline
\end{tabular}

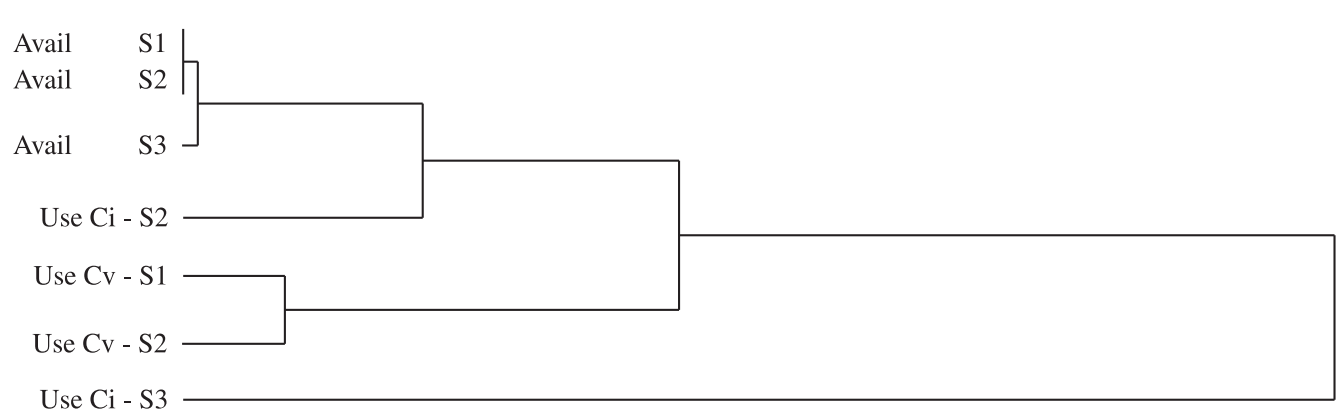

Figure 4. Dendrogram of similarity (Bray Curtis distance) based on available and consumed food items. Food items availability at site 1 (Avail S1), site 2 (Avail S2) and site 3 (Avail S3) and consumed food items by Characidium cf. vidali from site 1 (Use $\mathrm{Cv}-\mathrm{S} 1$ ) and site 2 (Use $\mathrm{Cv}-\mathrm{S} 2$ ) and Characidium interruptum from site 2 (Use $\mathrm{Ci}-\mathrm{S} 2$ ) and site 3 (Use $\mathrm{Ci}-\mathrm{S} 3$ ), from Mato Grosso stream, Rio de Janeiro, Brazil.

Prejs, 1987; Goulding et al., 1988; Casatti et al., 2001) making it reasonable to expect that during this period the feeding spectrum would be enlarged as fish change from preferred food items to the available ones (Zaret and Rand, 1971; Matthews, 1998). In fact, it was noticed that the IAi's values of preferred food items (Simuliidae, Trichoptera and Ephemeroptera) tended to be smaller during the dry season. Taking this into account, the occurrence of algae and plant items in the diet of both Characidium species could be interpreted as an opportunistic circumstance resulting from environmental conditions related to this season.

In fact the most significant variation of $C$. vidali and C. interruptum feeding habits were related to changes in the abundance of consumed prey within the insects, agreeing with the conclusions of Barreto and Aranha (2006) about the importance of environmental alterations, such as floods as the main cause for diet shifts of four characins from an Atlantic Rain Forest stream in Brazil. In addition, the feeding behaviour of Characidium species, described in Leitão et al. (2007), could help to explain these opportunistic and/or seasonal shifts in food consumption. Although the "sit-and-wait" foraging tactic used by Characidium species (e.g. Sazima, 1986; Aranha et al., 1998) supports the invertivore classification adopted in the present study, the opportunistic/circumstantial use of plant parts and algae could be explained by the findings of Leitão et al. (2007) about the "nuclear-follower association" feeding behaviour registered for a Characidium species from an Atlantic rain forest from southeast of Brazil. According to Leitão et al. (2007) this feeding behaviour involving one Characidium species was characterized by the presence of a nuclear species, in this case a Loricariidae catfish species, which causes some kind of disturbance on the bottom while foraging, and a follower species, in the case of a Characidium, which feeds on the dislodged sediment, algae and (possibly) small animals. Considering that two species of Loricarridae catfish co-exist with our $C$. vidale and $C$. interruptum (unpublished data), we can explain the observed pattern of feeding behavior during the dry season.
Biotic factors, such as predation and competition and abiotic factors, such as stream order and width, current velocity, degree of vegetal coverture and substrate diversity have been reported to influence local fish assemblage (Tejerina-Garro et al., 2005; Ibañez et al., 2009) and food availability (Rezende and Mazzoni, 2006a, b; Pinto and Uieda, 2007). These factors differ along spatial and temporal scales inducing general patterns of trophic organization and specific local responses (Uieda and Motta, 2007). Stream-dwelling fish predators are generalist and feed upon organisms from many different origins such as allochthonous invertebrates, including those present in the water surface and those that fall from the riparian vegetation, as well as autochthonous invertebrates such as immature forms of aquatic and terrestrial insects, crustaceans, oligochaetes and mollusks (Rezende et al., 2011). Such a feeding plasticity is responsible for temporal and spatial variations in feeding patterns of stream-dwelling fishes.

Spatial patterns in feeding habits were the most notable differences in the present study; no seasonal variation on feeding habits were registered. Although food availability was similar at all studied sites, niche breadth was smaller at sites where both $C$. vidali and $C$. interruptum did not co-exist, but were larger at Site 2 where both species were present. At the site of co-existence, $C$. vidali and $C$. interruptum consumed an almost identical array of prey items and presented a medium to high value of niche overlap. In contrast, in the site where they did not co-occur, both $C$. vidali and $C$. interruptum diets were based on completely distinct food items, although prey availability was the same in these sites. These results are contradictory to the expectations of the niche theory (Mac-Arthur, 1972), which predicts feeding segregation between closely-related species in response to a limited amount of resources. Although the theory is largely based on the idea that natural selection tends to lessen competition among closely-related species by making them consume different food items and favouring specialists (Cunha et al., 1951), there are still some contradictory opinions about 
the importance of specialists versus generalists in tropical communities (Wilson and Yoshimura, 1994), with many examples of both generalists and specialists (Vojtech et al., 2002; Dyer et al., 2007). Although the enlargement of niche breadth among coexisting species is paradigmatically counter to the niche theory, the statement postulated by Cunha et al. (1951), that feeding plasticity is an important strategy to maintain different populations could explain our results.

Contrary to current ecological expectations about coexisting species, we demonstrated that the two studied congeneric species tended to specialize feeding behaviour when living alone in a given site and to generalise behaviour when co-occurring in the same site. Considering that congeneric species tend to have similar environmental and/ or trophical requirements (Gerking, 1994) we can suppose that some other characters (e.g. Chase and Leibold, 2003), which were not measured in the present study, could explain the observed patterns of distribution and coexistence of the Characidium species from the Mato Grosso stream. In fact, many other behavioural and morphological traits (e.g. Casatti and Castro, 2006; Nunes and Hartz, 2006) have been indicated as being responsible for species coexistence in stream-dwelling fish communities from the Neotropical region.

Acknowledgments - We would like to thank the staff of the Laboratório de Ecologia de Peixes/Depto. de Ecologia/UERJ for assistance during the field work and to Beatrix Beisner and Pedro Peres-Neto for comments and editorial assistance. This work was supported by a grant from FAPERJ E/26-170.578/2006 and individual grants from CNPq to RM (301433/2007-0), CFR (140928/2005-7) and PSM (508476/2010-0). This study is part of the scientific initiation research of PSM.

\section{References}

ARANHA, MR., GOMES JHC. and FOGAÇA, FN., 2000. Feeding of two sympatric species of Characidium, C. Lanei and C. pterosticum (Characidiinae) in a coastal stream of Atlantic Forest (Southern Brazil). Brazilian Archives of Biology and Technology, vol. 43, p. 527-531. http://dx.doi.org/10.1590/ S1516-89132000000500013

ARANHA, MR., TAKEUTI, DF. and YOSHIMURA, TM., 1998. Habitat use and food partitioning of the fishes in a coastal stream of Atlantic Forest, Brazil. Revista de Biología Tropical, vol. 6 , p. 955-963.

ARAÚJO, FG., ANDRADE, CC., SANTOS, R. N., SANTOS, AFG. and SANTOS, LN., 2005. Spatial and seasonal changes in the diet of Oligosarcus hepsetus (Characiformes, Characidae) in a Brazilian reservoir. Brazilian Journal of Biology, vol. 65, p. 1-8. http://dx.doi.org/10.1590/S1519-69842005000100002

ARAUJO-LIMA, CARM., AGOSTINHO, AA. and FABRÉ, NN., 1995. Trophic aspects of fish communities in Brazilian rivers and reservoirs. In TUNDISI, JG., BICUDO, CEM., and T. MATSUMURA-TUNDISI, T. (Eds.). Limnology in Brazil. Rio de Janeiro: ABC/ABL. p. 105-136.

BARRETO, AP. and ARANHA, JMA., 2006. Alimentação de quatro espécies de characiformes de um riacho da Floresta
Atlântica Guaraqueçaba, Paraná, Brasil. Revista Brasileira de Zoologia, vol. 23, p. 779-788.

CARVALHO, EM. and UIEDA, VS., 2010. Input of litter in deforested and forested areas of a tropical headstream. Brazilian Journal of Biology, 70, no. 2, p. 283-288. http://dx.doi.org/10.1590/ S1519-69842010005000015

CASATTI, L. and CASTRO, RMC., 2006. Testing the ecomorphological hypothesis in a headwater riffles fish assemblage of the rio São Francisco, southeastern Brazil. Neotropical Ichthyology, vol. 4, p. 203-214.

CASATTI, L., LANGEANI, F., and CASTRO, RMC., 2001. Peixes de riacho do Parque Estadual do Morro do Diabo, bacia do alto rio Paraná, SP. Biota Neotropica, vol. 1, no. 1. Available from: <http://www.biotaneotropica.org.br/v1n12/pt/abstract?inv entory+bn00201122001>. Access in: 20fev. 2011.

CASTRO, RMC. and CASATTI, L., 1997. The fish fauna from a small forest stream of the upper Paraná River basin, Southeastern Brazil. Ichthyological Exploration of Freshwaters, vol. 7, no. 4, p. $337-352$

CHASE, JM. and LEIBOLD, MA., 2003. Ecological niches: linking classical and contenporary approaches. Chicago: University of Chicago. 212 p.

COSTA, WJEM., 1987. Feeding habits of a fish community in a tropical coastal stream, Rio Mato Grosso, Brazil. Studies on Neotropical Fauna \& Environment, vol. 22, p. 145-153. http:// dx.doi.org/10.1080/01650528709360728

CUNHA, AB., DOBZHANSKY, T. and SOKOLOFF, A., 1951. On food preferences of sympatric species of Drosophila. Evolution, vol. 2, p. 97-101.

DEUS, CP. and PETRERE-JUNIOR, M., 2003. Seasonal diet shift of seven fish species in an Atlantic rainforest stream in southeastern Brazil. Brazilian Journal of Biology, vol. 63 p. 579-588.

DYER, LA., SINGER, MS., LILL, JT., STIREMAN, JO., GENTRY, GL., MARQUIS, RJ., RICKLEFS, HF., GREENEY, HF., WAGNER, DL., MORAIS, HC., DINIZ, IR., KURSAR, TA. and COLEY, PD., 2007. Host specificity of Lepidoptera in tropical and temperate forests. Nature, vol. 448, p. 696-699.

ESTEVES, KE. and LOBÓN-CERVIÁ, J., 2001. Composition and trophic structure of a clear water Atlantic rainforest stream in southeastern Brazil. Environmental Biology of Fish, vol. 62, p. 429-440. http://dx.doi.org/10.1023/A:1012249313341

FERREIRA, KM., 2007. Biology and ecomorphology of stream fishes from the rio Mogi-Guaçu basin, Southeastern Brazil. Neotropical Ichthyology, vol. 5, p. 311-326.

FOGAÇA, FNO., ARANHA, JMR. and ESPER, MLP., 2003. Ictiofauna do rio do Quebra (Antonina, PR, Brasil): Ocupação espacial e hábito alimentar. Interciência, vol. 28, p. 168-173.

GERKING, SD., 1994. Feeding ecology of fishes. San Diego: Academic Press. 416 p.

GODOY, MP., 1975. Peixes do Brasil: Subordem Characoidei. Piracicaba: Editora Franciscana. 847 p.

GOMIERO, LM. and BRAGA, FMS., 2008. Feeding habits of the ichthyofauna in a protected area in the state of São Paulo, southeastern Brazil. Biota Neotropica, vol. 8, no. 1. Available from: <http://www.biotaneotropica.org.br/v8n1/en/abstract?inv entory+bn00608012008. Access in: 20 fev. 2011. 
GOULDING, M., CARVALHO, ML. and FERREIRA, EG., 1988. Rio Negro, Rich Life in Poor Water. The Hague: SBP Academic Publishing. 200 p.

GROSSMAN, GD., 1986. Food resources partitioning in a rocky intertidal fish assemblage. Journal of Zoology, vol. 1, p. 317-355.

HAHN, NS., ALMEIDA, VLL. and LUZ, KDG., 1997. Alimentação e ciclo alimentar diário de Hoplosternum littorale (Hancock) (Siluriformes, Callichthyidae) nas lagoas Guaraná e Patos da Planície do Alto Paraná, Brasil. Revista Brasileira de Zoologia, vol. 14, p. 57-64.

HUTCHINSON, GE., 1957. Concluding remarks. Ecology, vol. 22, p. 415-427.

HYNES, HBN., 1950. The food of freshwater sticklebacks (Gasterosteus aculeatus and Pygosteus pungintius), with a review of methods used in studies of the food fishes. Journal of Animal Ecology, vol. 19, p. 36-57. http://dx.doi.org/10.2307/1570

HYSLOP, EJ., 1980. Stomach contents analysis: a review of methods and their application. Journal of Fish Biology, vol. 17, p. 411-429. http://dx.doi.org/10.1111/j.1095-8649.1980.tb02775.x

IBAÑEZ, C., BELLIARD, J., HUGHES, RM., IRZ, P., KAMDEM-TOHAM, A., LAMOUROUX, N., TEDESCO, PA. and OBERDORFF, T., 2009. Convergence of temperate and tropical stream fish assemblages. Ecography, vol. 32, p. 658-670.

JEPSEN, DB., WINEMILLER, KO. and TAPHORN, DC., 1997. Temporal patterns of resource partitioning among Cichla species in a Venezuelan blackwater river. Journal of Fish Biology, vol. 51, p. 1085-1108.

KAWAKAMI, E. and VAZZOLER, G., 1980. Método gráfico e estimativa de índice alimentar aplicado no estudo da alimentação de peixes. Boletim do Instituto Oceanográfico, vol. 29, p. 205-207.

KIDO, MC., 2001. Food relations between coexisting native Hawaiian stream fishes. Environmental Biology of Fish, vol. 61, p. 185-194. http://dx.doi.org/10.1023/A:1011095526939

KREBS, CJ., 1999. Ecological Methodology. California: Addison Wesley Longman. 654 p.

LEITÃO, RP., CARAMASCHI, EP. and ZUANON, P., 2007. Following food clouds: feeding association between a minute loricariid and a characidiin species in an Atlantic Forest stream, Southeastern Brazil. Neotropical Ichthyology, vol. 5, p. 307-310.

LOWE-MCCONNELL, RH., 1979. Ecological aspects of seasonality in fishes of tropical waters. Proceedings of the Zoological Society of London, vol. 4, p. 219-241.

MAC-ARTHUR, RH., 1972. Geographical Ecology. New York: Harper and Row. 269 p.

MATTHEWS, WJ., 1998. Patterns in freshwater fish ecology. California: Chapman \& Hall. 756 p.

MAZZONI, R. and LOBÓN-CERVIÁ, J., 2000. Longitudinal structure, density and production rates of a neotropical stream fish assemblage: the river Ubatiba in the Serra do Mar, southeast Brazil. Ecography, vol. 23, p. 588-602. http://dx.doi.org/10.1034/j.16000587.2000.230510.x

MAZZONI, R. and REZENDE, CF., 2009. Daily Feeding Activity of Bryconamericus microcephalus (Characiformes, Characidae) From Córrego Andorinha, Ilha Grande - RJ. Revista Brasileira de Biologia = Brazilian Journal of Biology, vol. 69, no. 2, p. 631-637.
MAZZONI, R., REZENDE, CF. and MANNA, LR., 2010a. Feeding ecology of Hypostomus punctatus Valenciennes, 1840 (Osteichthyes, Loricariidae) in a costal stream from Southeast Brazil. Brazilian Journal of Biology, vol. 70, no. 3, p. 569-574. http://dx.doi.org/10.1590/S1519-69842010000300013

MAZZONI, R., MORAES, M., REZENDE, CF. and IGLESIASRIOS, R., 2010b. Diet and feeding daily rhythm of Pimelodella lateristriga (Osteichthyes, Siluriformes) in a coastal stream from Serra do Mar - RJ. Brazilian Journal of Biology, vol. 70, no. 4, p. 1123-1129. http://dx.doi.org/10.1590/S1519-69842010000500031

McCUNE, B. and MEFFORD, MJ., 1997. PC-ORD: Multivariate Analysis of Ecological Data. Version 3,0.MjM. Oregon: Software Design.

MUGNAI, R., NESSIMIAN, JL. and BAPTISTA, DF., 2010. Manual de identificação de macroinvertebrados aquáticos do Estado do Rio de Janeiro. Rio de Janeiro: Technical Books Editora. 174 p.

NUNES, DM. and HARTZ, SM., 2006 Feeding dynamics and ecomorphology of Oligosarcus jenynsii (Gunther, 1864) and Oligosarcus robustus (Menezes, 1969) in the Lagoa Fortaleza, southern Brazil. Brazilian Journal of Biology, vol. 66, p. 121-132. http://dx.doi.org/10.1590/S1519-69842006000100016

PINTO, TLF. and UIEDA, VS., 2007. Aquatic insects selected as food for fishes of a tropical stream: are there spatial and seasonal differences in their selectivity? Acta Limnologica Brasiliensis, vol. 19 , no 1 , p. 67-78.

PREJS, A. and PREJS, K., 1987. Feeding of tropical freshwater fishes: seasonality in resource availability and resource use. Oecologia, vol. 71, p. 397-404. http://dx.doi.org/10.1007/ BF00378713

PUSEY, BJ. and BRADSHAW, SD., 1996. Diet and dietary overlap in fishes of temporary Waters of southwestern Australia. Ecology of Freshwater Fish, vol. 5, p. 183-194. http://dx.doi. org/10.1111/j.1600-0633.1996.tb00132.x

REZENDE, CF. and MAZZONI, R., 2006a. Contribuição da matéria autóctone e alóctone para a dieta de Bryconamericus microcephalus (Miranda-Ribeiro) (Actinopterygii, Characidae), em dois trechos de um riacho de Mata Atlântica, Rio de Janeiro, Brasil. Revista Brasileira de Zoologia, vol. 23, no. 1, p. 58-63.

-, 2006b. Disponibilidade e uso de recursos alóctones por Bryconamericus microcephalus (Miranda-Ribeiro) (Actinopterygii, Characidae), no córrego Andorinha, Ilha Grande, Rio de Janeiro, Brasil. Revista Brasileira de Zoologia, vol. 23, no. 1, p. 218-222. http://dx.doi.org/10.1590/S0101-81752006000100014

REZENDE, CF., MAZZONI, R., CARAMASCHI, EP., RODRIGUES, D. and MORAES, M., 2011. Prey selection by two benthic fish species in the Mato Grosso stream, SaquaremaRJ, Brazil. Revista de Biología Tropical, vol. 59, p. 1697-1706.

SABINO, J. and CASTRO RMC., 1990. Alimentação, período de atividade e distribuição espacial dos peixes de um riacho da floresta Atlântica (Sudeste do Brasil). Revista Brasileira de Biologia = Brazilian Journal of Biology, vol. 50, no. 1, p. 23-36.

SAZIMA, I., 1986. Similarities in feeding behavior between some marine and freshwater fishes in two tropical communities. Journal of Fish Biology, vol. 29, p. 53-65. http://dx.doi. org/10.1111/j.1095-8649.1986.tb04926.x

SÚAREZ, YR., 2008. Spatial and temporal variation in fish species diversity and composition in streams of Ivinhema River basin, upper Paraná River. Biota Neotropica, vol. 8, no. 3. Available 
from: <http://www.biotaneotropica.org.br/v8n3/en/abstract?art icle+bn02308032008>.

UIEDA, VS., BUZZATO, P. and KIKUCHI, RM., 1997. Partilha de recursos alimentares em peixes em um riacho de serra do sudeste do Brasil. Anais da Academia Brasileira de Ciências, vol. 69 , p. 243-252.

UIEDA, VS. and MOTTA RL., 2007. Trophic organization and food web structure of southeastern Brazilian streams: a review. Acta Limnologica Brasiliensis, vol. 19, no. 1, p. 15-30.

VOJTECH, N., BASSET, Y., MILLER, SE., WEIBLEN, GD., BREMER,B., CIZEK, L. and DROZD, P., 2002. Low host specificity of herbivorous insects in a tropical forest. Nature, vol. 416, p. 841-844. PMid:11976681. http://dx.doi.org/10.1038/416841a
WILSON, DS. and YOSHIMURA, J., 1994. On the coexistence of specialists and generalists. American Naturalist, vol. 144, p. 692-707. http://dx.doi.org/10.1086/285702

WINEMILLER, KO., 1989. Patterns of variation in life history among South American fishes in seasonal environmentals. Oecologia, vol. 81, p. 225-241.

WINEMILLER, KO. and JEPSEN, DB., 1998. Effects of seasonality and fish movement on tropical river food webs. Journal of Fish Biology, vol. 53, p. 267-296. http://dx.doi. org/10.1111/j.1095-8649.1998.tb01032.x

ZAR, JH., 1999. Biostatistical analysis. New Jersey: PrenticeHall. 662 p.

ZARET, TM. and RAND, AS., 1971. Competition in tropical stream fishes: Support for the competitive exclusion principle. Ecology, vol. 52, p. 336-342. 